Liturgia Sacra 24 (2018), nr 1, s. 105-126

DOI: $10.25167 / \mathrm{LitS} / 24(2018) 1 / 105-126$

KAROL LitAWA

UKSW - WSD w Łodzi; Instytut Teologiczny - Łódź; UPJPII

\title{
Obrzęd nałożenia paliusza metropolitom - historia i teologia
}

Pallium - łaciński rzeczownik rodzaju nijakiego oznacza przede wszystkim płaszcz grecki w formie długiego, wełnianego szala, którym owijano całe ciało, a także osłaniano głowę ${ }^{1}$. Drugie jego znaczenie określa zasłonę, zwłaszcza wełnianą, brokatową albo jedwabną, zdobiącą niższą część ołtarza (antepedium) lub baldachim. Wreszcie pallium to paliusz biskupi, nadany z Rzymu, oznaka metropolity: „,iała wełniana taśma z wszytymi czarnym jedwabiem sześcioma krzyżami, opierająca się na ramionach, a spadająca z przodu i z tyłu na ornat" ${ }^{2}$ i odpowiednio przyczepiony metalowymi spinkami ${ }^{3}$. Do XIII w. zamiast czarnego jedwabiu używano czerwonej purpury do wyszywania krzyży ${ }^{4}$. Kolejne wieki zapisały na kartach swej historii dokumentację zmian zarówno zewnętrznej, jak i celebracyjnej formy związanej z insygnium - znakiem jedności i łączności papieża z biskupami odpowiedzialnymi za lokalne wspólnoty uczniów Chrystusa.

Historia związana z używaniem paliusza przez metropolitów, jego liturgicznym błogosławieństwem i uroczystym nałożeniem, staje się zatem motywem pogłębionej refleksji dotyczącej najważniejszych etapów jego historii aż do ostatniej modyfikacji obrzędu dokonanej w 2015 r.

${ }^{1}$ A. Jougan, Słownik kościelny łacińsko-polski, Sandomierz 20135', s. 476.

2 Tamże.

${ }^{3}$ B. NADOLSKI, Leksykon liturgii, Poznań 2006, s. 1139.

${ }^{4}$ Do późnego średniowiecza krzyże były koloru purpurowego - por. G. Morin, Le pallium, „Le Messager des fidèles. Revue Bénédictine" 6 (1889), s. 258. Na dowód należy przywołać papieża Innocentego III (1179-1180 r.), który opisując swój paliusz zaznaczył, iż znajdują się na nim cztery purpurowe krzyże. Por. InNocenzo III, Il Sacrosancto mistero dell'altare, S. Fioramonti, M. Sodi (red.), Città del Vaticano 2002, s. 25. 


\section{Historia}

Początki paliusza nie są do końca znane. Pierwotnie pojęciem tym określano płaszcz używany przez filozofów, a w sztuce paleochrześcijańskiej w takim płaszczu przedstawiano Chrystusa i Apostołów ${ }^{5}$. Thomas F. Mathews uważa, że przedstawianie Jezusa i Jego uczniów w paliuszu (płaszczu) potwierdzało pewien dystans do świata i naukę o ,innym świecie”, która w epoce późnoimperialnej była powszechnie głoszona przez filozofów ${ }^{6}$. Jarosław Superson podkreśla, że „szata spoczywała na Jego [Chrystusa] lewym ramieniu, okrywała Jego plecy, nie osłaniała prawego ramienia, lecz znajdowała się pod Nim"”.

W pierwszych wiekach chrześcijaństwa paliusz jako rodzaj szala skrzyżowanego na lewym ramieniu noszony był prawdopodobnie przez wszystkich biskupów ${ }^{8}$. Starożytna ikonografia chrześcijańska przedstawia pierwszych papieży i świętych biskupów przyodzianych w paliusz (św. Ambroży, św. Atanazy, św. Jan Chryzostom, św. Ignacy z Antiochii i in.). Ze swego kunsztu artystycznego słynie również mozaika przedstawiająca św. Apolinarego z paliuszem na ramionach znajdująca się na sklepieniu apsydy w bazylice Sant'Apollinare in Classe w Rawennie.

Paliusz jako szatę liturgiczną papieża spotykamy już w IV w. za pontyfikatu św. Marka (336 r.), który według Liber Pontificalis ${ }^{9}$ powierzył ją biskupowi Ostii, jednemu z konsekrujących papieża ${ }^{10}$. Jeśli nawet nie ma pewności co do wiarygodności historycznej tej informacji, to przynajmniej można przypuszczać, że taka praktyka była stosowana w Kościele pomiędzy IV a VI w., kiedy Liber Pontificalis było kompilowane w kręgach Kurii Rzymskiej.

Tradycja noszenia szat liturgicznych z czasem ulegała zmianom, jednak od zawsze - według Antoniego Nowowiejskiego - zaliczał się do niej paliusz ${ }^{11}$. Pierws. 27.

5 T.F. Mathews, Scontro di dei. Una reinterpretazione dell'arte paleocristiana, Milano 2005,

${ }^{6}$ Tamże.

7 J. Superson, Paliusz - wspótczesna forma i teorie o pochodzeniu, ,Ruch Biblijny i Liturgiczny", t. LXV (2012), nr 1, s. 89. s. 5.

${ }^{8}$ Zob. J.M. Martí Bonet, El palio. Insignia pastoral de los papas y arzobispos, Madrid 2008,

${ }^{9}$ Hic constituit uti episcopus Ostiae, qui consecrat episcopum, palleum uteretur, et ab eodem episcopus urbis Romae consecraretur (C. Vogel, L. Duchesne [ed.], Liber pontificalis. Texte introduction, et commentaire, t. I, Paris 1955-1957, s. 202-203, n. 2).

${ }_{10}$ Zob. M. Righetti, Manuale di storia liturgica, t. I: Introduzione generale, Milano $2005^{2}$, s. $625-626$.

${ }_{11}$ Por. A. NowowIEJSKI, Wykład Liturgji Kościoła Katolickiego, t. II, cz. 1: O środkach rozwinięcia kultu, Warszawa 1902, s. 440. 
sze informacje historyczne dotyczące paliusza pochodzą z chrześcijańskiej starożytności. Choć czasem twierdzi się, że paliusz należał do stroju rzymskich oficerów państwowych, a później także noszony był przez duchownych dygnitarzy, jezuita Joseph Braun sugeruje jego kościelne pochodzenie ${ }^{12}$. Według niemieckiego uczonego papieże chcieli używać od samego początku świętego paliusza jako własnego sztandaru i chusty liturgicznej ${ }^{13}$.

Od IV w. zaczęto używać paliusza podczas ordynacji biskupiej ${ }^{14}$. Papieże tego okresu, powierzając zwierzchnictwo poszczególnym biskupom nad innymi biskupami, wysyłali im fragment materiału pochodzący z płaszcza św. Piotra. Ten gest oznaczał udział biskupów we władzy prymatu św. Piotra, którą posiadał tylko papież ${ }^{15}$.

Pierwsza wiarygodna wzmianka o nałożeniu paliusza biskupowi sięga 513 r., kiedy papież Symmachus (498-514 r.) przekazał insygnium bp. Cezaremu z Arles, którego ustanowił swoim wikariuszem w Galii ${ }^{16}$ :

Papa Symmachus tanta meritorum eius dignitate permotus, non solum verissime eum metropolitanae honore suspexit sed et concesso specialiter pallii decoravit privilegio ${ }^{17}$.

Kilkanaście lat później, między 545 a 546 r., papież Wigiliusz (537-555 r.) czyni to samo wobec następców biskupa z Arles, Oskaniusza (22 maja 545 r.) i Aureliana (23 sierpnia 546 r. $)^{18}$. Od tego czasu mnożą się świadectwa dotyczące praktyki nakładania przez papieża paliusza biskupom Italii oraz innym pochodzącym spoza jej granic ${ }^{19}$. Papież Grzegorz Wielki (590-604 r.) uczynił ostatecznie z paliusza instrument wewnętrznej i zewnętrznej polityki kościelnej, posługując się nim do

${ }_{12}$ Zob. J. Braun, Die liturgischen Paramente in Gegenwart und Vergangenheit. Ein Handbuch der Paramentik, Bonn 2005, s. 143-151.

13 Tamże.

14 Por. P. Marini, Liturgia i Piękno, Pelplin 2007, s. 120-121.

15 Por. J.M. Martí Bonet, El palio, s. 5.

16 Zob. B. Nadolski, Paliusz w: Leksykon liturgii, s. 1140.

17 Vita S. Cesarii, 4, 20, w: J.P. Migne, Patrologiae Cursus Completus. Series Latina, PL 67, Paris 1844-1864, s. 1016. Według tradycji w Arles przechowywany jest do dziś paliusz św. Cezarego. Utkany został z białej wełny i widnieje na nim monogram Chrystusa. Jego długość wynosi $240 \mathrm{~cm}$, natomiast szerokość $9 \mathrm{~cm}$ (zob. M. Righetti, Manuale di storia liturgica, t. I, s. 626).

18 Zob. J.M. Martí Bonet, El palio, s. 12; M. Righetti, Manuale di storia liturgica, t. I, s. 626.

${ }^{19} \mathrm{~Np}$. św. Grzegorz Wielki przekazuje paliusz biskupom: Janowi z Palermo, Janowi z Syrakuz, Donusowi z Messyny, Konstantemu z Mediolanu, Leonardowi z Sewilli, Maksymowi z Salony w Dalmacji, Syagriuszowi z Autun, Wirgiliuszowi z Arles. (zob. M. Righetti, Manuale di storia liturgica, t. I, s. 626; J.M. Martí Bonet, El palio, s. 20-33). 
wdrażania i zacieśniania związków ze Stolicą Apostolską ${ }^{20}$. Nie posiadamy natomiast historycznej wzmianki o możliwości nakładania paliusza przez inne niż papież osoby za wyjątkiem specjalnego przywileju Stolicy Świętej ${ }^{21}$. Na podstawie korespondencji Grzegorza można wnioskować, że papież miał pełną swobodę w nadawaniu biskupom paliusza, bez powoływania się na autorytet cesarza, jak również mógł swobodnie pozbawiać jakiegoś biskupa paliusza, zwłaszcza z przyczyn związanych z dyscypliną kościelną 22 .

Z kolei w Egipcie św. Izydor z Peluzji (360-440 r.) wspomina paliusz biskupi,

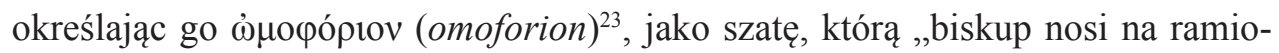
nach" ( bionej owieczki, której szukał Pan; a znalazłszy, wziął ją na ramiona"24.

W swoim historycznym rozwoju paliusz stał się symbolem szczególnej więzi z Biskupem Rzymu, a także wyrażał moc, którą w komunii z Rzymem metropolita nabywa prawnie dla własnej jurysdykcji.

Według J. Brauna papieże od samego początku (bezpośrednio w sukcesji po św. Piotrze) uznali paliusz jako insygnium liturgiczne przysługujące im samym. $\mathrm{Z}$ zachowanych tekstów z okresu poprzedzającego pontyfikat Grzegorza Wielkiego można z pewnością wnioskować, że paliusz był w użyciu od początku VI w. ${ }^{25}$ Należy zauważyć, że paliusz w swych najstarszych przedstawieniach prezentowany jest jako szarfa całkowicie otwarta i umieszczona na ramionach. Przykład takiej formy paliusza można odnaleźć w mozaikowym przedstawieniu św. biskupa Maksymiana (498-556 r.) w San Vitale w Rawennie (pierwsza połowa VI w.).

${ }^{20}$ Zob. J. Lewandowicz, Paliusz w korespondencji świętego Grzegorza Wielkiego, „Vox Patrum” 24 (2004), t. XLVI-XLVII, s. 364; J.M. MarTí Bonet, El palio, s. 19.

${ }^{21} \mathrm{~W}$ Żywocie św. Fulgencjusza, biskupa Ruspe († ok. 530 r.) czytamy: Subtus casulam nigello vel lactinio pallio circumdatus incessit. Quando temperies aeris invitabat, solo pallio intra monasterium est coopertus. Scapulis vero nudis numquam a nobis visus est (Vita S. Fulgentii, w: J.P. Migne, PL 18, 37, 65, Paris 1844-1864, s. 136).

${ }^{22}$ Zob. J. Lewandowicz, Paliusz w korespondencji, s. 367; papież Grzegorz grozi m.in. biskupowi Salony w Dalmacji - Natalisowi, iż pozbawi go możliwości używania paliusza, jeśli nie zmieni swojego postępowania szczególnie w odniesieniu do archidiakona Honorata, którego biskup usiłował pozbawić urzędu (Gregorius Magnus, Epistolae II, 17-18, [Corpus Christianorum Series Latina 140], Turnhout 2015, s. 102-105).

${ }^{23}$ Omoforion - odpowiednik paliusza - od IV w. stał się liturgiczną oznaką biskupa w obrządku bizantyjskim. To długa $(3,5 \mathrm{~m})$ i szeroka $(25 \mathrm{~cm})$ stuła z wyszytymi krzyżami tego samego koloru co ornat nakładany na ramiona. Współcześnie istnieje tendencja do używania omoforionu z białego jedwabiu i z czarnymi krzyżami z lewej i prawej strony oraz dwóch lub trzech tasiemek. W przeciwieństwie do paliusza, omoforion nie jest zarezerwowany dla arcybiskupów metropolitów, ale mogą być noszone przez wszystkich biskupów (zob. B. NADOLSKI, Leksykon liturgii, s. 1100-1101).

24 Isidorus di Pelusio, Epistula I, 136, PG 78, Paris 1854, s. 721.

25 Zob. J. Lewandowicz, Paliusz w korespondencji, s. 364. 
Reasumując, zwyczaj noszenia paliusza posiada bardzo odległą w czasie historię: oficjalnie nadawany jest w Kościele od V/VI w.; IV Sobór Konstantynopolitański (869/870 r.) ustalił, że każdy patriarcha ma prawo ustanawiać metropolitów, a potwierdzeniem tej godności był właśnie paliusz. Sobór zaznacza jednak, że patriarchowie nie otrzymywali paliusza z rąk papieskich, a jednak sami nadawali go metropolitom ${ }^{26}$. Ponadto rzeczony Sobór nakazuje nosić paliusz podczas sprawowania Eucharystii w czasie do tego przeznaczonym ${ }^{27}$ :

\begin{abstract}
Nakazujemy, aby biskupi, którym przyznano noszenie paliusza w wyznaczonych i stosownych chwilach, zakładali go tylko w tym czasie i w ustalonych miejscach, nie używali tego stroju z pychy i próżności oraz nie nosili go przez cały czas trwania Bożej mystagogii i wszystkich innych kościelnych akcji liturgicznych. Jeśli więc jakiś biskup przywdzieje na siebie paliusz poza czasem ustalonym na piśmie lub ustnie lub pozbędzie się szat zakonnych, albo się poprawi, albo zostanie zdjęty z urzędu ${ }^{28}$.
\end{abstract}

Za sprawą IV Soboru w Konstantynopolu w 869 r. wprowadzono znaczące zmiany związane z nadawaniem paliusza ${ }^{29}$. Nakładany był on tylko arcybiskupom, prymasom i patriarchom. Wyjątek stanowili biskupi, którzy nie zostali odznaczeni godnością arcybiskupią, ale ze specjalnego nadania przez Ojca Świętego mogli zakładać paliusz ${ }^{30}$. Przez te zmiany Sobór podkreślił wielką godność i doniosłość tej szaty, bez której nie można było otrzymać nominacji arcybiskupiej oraz sprawować czynności pontyfikalnych ${ }^{31}$.

Używanie paliusza wiązało się zazwyczaj z powszechnie używanym zwyczajem lokalnego Kościoła. Papieże posyłając paliusz biskupom podkreślali, że każdy ma obowiązek używania go w sposób, jak to czynili jego poprzednicy ${ }^{32}$.

26 Por. A. Nowowiejski, Wykład Liturgji, s. 442.

27 A. Baron, H. Pietras (red.), Dokumenty Soborów Powszechnych. Tekst grecki, taciński, polski, t. II: (869-1312), Kraków 2003, s. 104-105.

28 Tamże.

29 Por. B. NADOLSKI, Leksykon liturgii, s. 1140.

${ }^{30}$ Por. A. NowowIEJSKI, Wyktad Liturgji, s. 445. Autor podaje biskupów, którzy w tamtych czasach posiadali ten przywilej: we Francji - biskupi Autun, Puy, Valence, Marsylii, oraz Clermont. We Włoszech - biskup Osti (jest to najstarszy przywilej z ok. 335 r.), biskupi Pawi, Arezzo, Anagni (z mianowania papieża Leona XIII) oraz w Lukce. Na Węgrzech - biskup pięciu Kościołów (od 7 IX 1754 r.). W Polsce - biskup warmiński (z nadania papieża Benedykta XIV, 21 IV 1742 r.).

${ }^{31}$ Por. tamże; P. SzCZESSNY, Paliusz. Historia - liturgia - teologia (praca magisterska w bibliotece UMK), Toruń 2015, s. 26.

32 Por. J. Lewandowicz, Paliusz w korespondencji, s. 369. 
Kolejne znaczące wzmianki historyczne odnośnie do paliusza odnajdujemy dopiero około IX w. A. Nowowiejski, badając historię paliusza, podkreśla dwa synody, które odbyły się w tym czasie: w Rawennie (877 r.) oraz w Troyes (878 r.), podczas których zadecydowano, aby metropolici trzy miesiące po swojej konsekracji wysłali do Rzymu podpisane przez siebie wyznanie wiary oraz prośbę o nałożenie paliusza $^{33}$. Ponadto wspomina o udzieleniu przez papieża Jana VIII (872-882 r.) godności paliusza biskupowi z Metz, zaznaczając, że używać go może tylko w wyznaczonym czasie podczas liturgii Mszy św. ${ }^{34}$

W X w., za pontyfikatu papieża Jana XIII (965-972 r.), odnajdujemy kolejną wzmiankę dotyczącą czasu używania paliusza, związaną z konkretnymi świętami i uroczystościami ${ }^{35}$. Również w tym czasie zostały wprowadzone pewne zmiany w sposobie nakładania oraz objętości paliusza, powodowane względami praktycznymi, mianowicie jego ciężar i ułożenie powodowało zsuwanie się paliusza z ramion celebransa, dlatego zaczęto przypinać go do ornatu ozdobnymi szpilkami. Jeden jego koniec opadał z przodu, drugi zaś na plecy biskupa, tworząc literę „Y”; sięgały do zakończenia ornatu ${ }^{36}$. W celu ozdobienia paliusza, do dwóch zakończeń przyszywano tzw. pedalia, czyli tkaninę obszywaną frędzlami lub zakończoną małymi dzwonkami ${ }^{37}$. Okrąg okalający szyję celebransa nazywano circulus, natomiast opadające z przodu i z tyłu końce - lineae $e^{38}$.

Wspomniane ozdobne szpilki pełniły podwójną rolę: ozdobną i służebną, gdyż przytwierdzały paliusz do ornatu, sprawiając jego stabilne i należyte ułożenie na ramionach celebransa. Jako dowód może posłużyć jedenastowieczny zapisek biskupa Segni Brunona (1045-1123 r.), w którym zauważa on, że „szpilki nie są przeznaczone do kłucia, jak niektórzy sądzą, dla sprawienia boleści, ale dla przytwierdzenia paliusza do ornatu. Niegdyś były pierścienie, za które się zakładało szpilki i paliusz przytwierdzał się do ornatu, stając się nieruchomym"39. Papież Innocenty III (1198-1215 r.) z kolei tłumaczy, że trzy szpile znajdujące się w purpurowych wyszytych krzyżach ${ }^{40}$, a umieszczone na piersi i na ramieniu oznaczają najpierw

${ }^{33}$ Por. A. NowowIEJSKI, Wyktad Liturgji, s. 445.

34 Tamże.

${ }^{35}$ Por. tamże, s. 446. Boże Narodzenie, Epifania, Wielki Czwartek, Niedziela Wielkanocna, Wniebowstąpienie, Zesłanie Ducha Świętego, uroczystości Matki Bożej, św. Jana Chrzciciela, Apostołów, Wszystkich Świętych, patrona miasta oraz dedykacji kościoła.

36 Tamże, s. 443; P. SzczęSNy, Paliusz, s. 25.

37 Por. A. NowowIEJSKI, Wyktad Liturgji, s. 444.

38 Por. M. Nowodworski, Encyklopedia Kościelna, Warszawa 1892, s. 46.

39 Cyt. za: A. NowowIEJski, Wykład Liturgji, s. 444.

${ }^{40}$ InNOCENZo III, Il Sacrosancto mistero, s. 95. 
współczucie względem bliźniego, dalej urząd arcybiskupa i posługę wyrażoną we władzy sądzenia jemu należnej ${ }^{41}$.

Antoni Nowowiejski zaznacza ponadto, że w inwentarzu Bonifacego VIII (1293-1303 r.) znajdują się również szpilki do paliusza, które przyozdabiane były drogimi kamieniami, np. rubinami, szafirami czy perłami ${ }^{42}$.

U schyłku epoki średniowiecza paliusz przyjmował coraz mniejszą formę ${ }^{43}$, by w XVII w. ostatecznie przyjąć wygląd taki, jaki nosili papieże aż do czasu Jana Pawła II.

Pontyfikał Rzymski z 1600 r. podaje konkretne wytyczne odnośnie do posiadających przywilej noszenia paliusza. Arcybiskup z prawem noszenia paliusza, bez wcześniejszego nałożenia go, nie miał prawa konsekrować żadnego biskupa, zwoływać synodu prowincjalnego, wizytować swojej prowincji kościelnej, kościołów, a ponadto nie mógł nakazać nieść przed sobą krzyża ${ }^{44}$.

Od XII w. paliusz otrzymywali arcybiskupi metropolici ${ }^{45}$. Zanim został im nałożony mogli oni sprawować wszystkie czynności pontyfikalne związane z biskupstwem $^{46}$. Od wieków istniała zasada podkreślająca możliwość noszenia paliusza w Kościele na całym świecie przez papieża podczas sprawowania czynności pontyfikalnych. Natomiast metropolici oraz prymasi mogli nosić paliusz tylko na terenie własnej metropolii, patriarchowie tylko w swoim patriarchacie, arcybiskupi w swojej archidiecezji, a biskupi obdarzeni godnością paliusza tylko w swojej diecezji ${ }^{47}$.

Wyjątki od tych zasad mogły powstać tylko i wyłącznie poprzez wyraźne orzeczenie papieża. Jako przykład możemy podać arcybiskupa Nazaretu, który mógł używać paliusza na całym świecie ${ }^{48}$. Posiadający przywilej noszenia paliusza związani byli z pewnymi ograniczeniami: nie mogli zakładać go w obecności papieża lub kardynała legata, nawet jeśli przebywali w swojej metropolii, natomiast biskupi

${ }^{41}$ Por. tamże, s. 99.

${ }^{42}$ Zob. A. Nowowiesski, Wykład Liturgji, s. 445.

43 Tamże.

44 Por. A. NowowIEJSKI, Wykład Liturgji, s. 446.

${ }^{45}$ B. NAdOLSKI, Leksykon liturgii, s. 213. 11 maja 1978 r. papież Paweł VI na mocy motu proprio „Inter ex ima pontificalis” doprecyzował noszenie paliusza, rezerwując go jedynie dla metropolitów oraz patriarchy łacińskiego Jerozolimy.

46 Por. A. Nowowiejski, Wyktad Liturgji, s. 446.

${ }^{47}$ Por. K. Schatz, Prymat papieski od początków do wspótczesności, tłum. E. Marszał, J. Zakrzewski, Kraków 2004, s. 105.

${ }^{48}$ Tamże. Przywileju tego, jak zauważa autor, udzielali kolejno papieże: Klemens VII, Klemens VIII, Innocenty III oraz Pius V. 
uprzywilejowani do nakładania tej szaty nie mieli prawa używać paliusza w obecności swojego metropolity ${ }^{49}$. Po wtóre, paliusza można było używać tylko podczas Mszy pontyfikalnych. Po trzecie istniało prawo zezwalające na noszenie paliusza w konkretne dni. Pontyfikał Duranda wskazuje np. konkretne święta oraz uroczystości, tzw. festa pallii, podczas których celebrans nakładał paliusz ${ }^{50}$. Zakazano ponadto używania paliusza podczas liturgii pogrzebowej.

Po Soborze Watykańskim II paliusz zachował renesansowy kształt ${ }^{51}$. W Jubileuszowym Roku 2000, na prośbę Urzędu Papieskich Celebracji Liturgicznych, został przygotowany nowy paliusz, który wykonały mniszki benedyktynki z klasztoru św. Cecylii w Rzymie. Utkany na wzór antycznego paliusza papieskiego, którego wzorem stała się mozaika Paschalisa I (817-824 r.) z kościoła św. Cecylii na Zatybrzu, został nałożony Janowi Pawłowi II podczas Mszy św. „pasterki”, inaugurującej Jubileusz ${ }^{52}$. Paliusz ten charakteryzował się nieco większym rozmiarem i miał kształt litery tau; ponadto ozdobiony był czerwonymi krzyżami, które podkreślały wymiar chrystologiczny tej szaty ${ }^{53}$.

Wybór nowego papieża, Benedykta XVI (2005-2013 r.), skłonił arcybiskupa Piero Mariniego, ówczesnego Mistrza Papieskich Ceremonii Liturgicznych, aby przygotować nową formę paliusza. Paliusz ten o długości $4 \mathrm{~m}$ i szerokości $10 \mathrm{~cm}$ nawiązywał do pierwotnego wzoru rzymskiego ${ }^{54}$. Jego ozdobą było pięć wyhaftowanych na czerwono krzyży, które symboliką nawiązywały do pięciu ran Chrystusa, natomiast zakończone zostały czarną tkaniną symbolizującą kopytka jagniąt. Jednak po krótkim czasie, jak podkreśla nowy ceremoniarz, Guido Marini, paliusz uległ modyfikacji ${ }^{55}$. Kolejny nowy paliusz przyjął kształt okręgu, ozdobionego

49 Por. M. Nowodworski, Encyklopedia, s. 47. Wyjątek stanowił kardynał biskup Ostii, który w swojej diecezji nosił paliusz bez ograniczeń.

${ }^{50}$ M. Andrieu (wyd.), Le Pontifical de Guillaume Durand, [Studi e Testi 88], Città del Vaticano 1940. Ristampa anastatica, Modena 1996, s. 661-662. Wilhelm Durand wskazuje konkretne uroczystości i święta oraz okoliczności, podczas których nakłada się paliusz, m.in. Boże Narodzenie, św. Szczepana, Jana Apostoła, Nowy Rok, Epifania, Niedziela Palmowa, Wielki Czwartek oraz Wielka Sobota. Kolejnymi dniami są: niedziela Zmartwychwstania Pańskiego, Wniebowstąpienie, św. Jana Chrzciciela, Boże Ciało oraz w pięć uroczystości Najświętszej Maryi Panny, uroczystość Wszystkich Świętych, w dni dedykacji kościołów, główniejsze uroczystości kościoła metropolitarnego, podczas święceń, w rocznicę swojej konsekracji.

${ }^{51}$ Por. P. MarinI, Ceremoniarz papieski. Rozmowy o liturgii przeprowadzit Dominique Chivot $i$ Vincent Cabanac, Katowice 2010, s. 122.

52 Por. M.G. Valenziano, Il pallium Il pallium papale, w: Ufficio delle Celebrazioni Liturgiche del Sommo Pontefice, Inizio del ministero Petrino del vescovo di Roma Benedetto XVI, Vaticano 2006, s. 377.

53 Por. P. Marini, Ceremoniarz papieski, s. 122.

${ }^{54}$ Zob. tamże, s. 8.

55 Por. J. Superson, Paliusz - wspótczesna forma, s. 87. 
czarnymi wypustkami oraz sześcioma czerwonymi krzyżami. Kształtem, kolorem krzyży oraz większym rozmiarem różni się od paliusza metropolity, przez co została podkreślona najwyższa jurysdykcja papieża w Kościele.

Papież Franciszek podczas Mszy św. inaugurującej jego pontyfikat przyjął paliusz identyczny do używanego w ostatnim czasie przez Benedykta XVI, jednak po dwóch latach powrócił do tzw. „paliusza arcybiskupiego”, podkreślając przez to więź łączącą metropolitów ze Stolicą Apostolską ${ }^{56}$. Od tej pory paliusz papieski i arcybiskupi (metropolitalny) ma taki sam rozmiar i ozdobiony jest czarnymi krzyżami.

\section{Obrzęd poświęcenia i nałożenia paliusza}

Obrzęd poświęcenia oraz nałożenia paliusza przyjmował rozmaite formy na przestrzeni dziejów, ulegając modyfikacji. W swoim studium A. Nowowiejski podkreśla, iż do XVIII w. obrzęd poświęcenia paliuszy poprzedzały długie modlitewne czuwania oraz nabożeństwa, a szafarzem był kardynał archiprezbiter Bazyliki św. Piotra lub jeden z kanoników - biskupów. Poświęcenie insygniów dokonywało się w porze porannej, tuż po jutrzni, w uroczystość świętych Piotra i Pawła - paliusze kładziono na ołtarzu tuż nad grobem św. Piotra i pozostawały tam przez całą oktawę uroczystości, a następnie przenoszone były do oratorium znajdującym się przy zakrystii ${ }^{57}$.

Benedykt XIV (1740-1758 r.), wzorem swego poprzednika Benedykta XIII (1724-1730 r.), osobiście dokonywał poświęcenia paliuszy przeznaczonych dla metropolitów, a w konstytucji Rerum ecclesiasticarum ${ }^{58}$ z 12 sierpnia 1748 r. przedstawił uproszczony obrzęd poświęcenia w wigilię uroczystości świętych Piotra i Pawła. Opuszczono czuwania poprzedzające poświęcenie, natomiast miejscem obrzędu stały się podziemia Bazyliki - tuż przy grobie św. Piotra. Po uroczystych nieszporach poświęcenia dokonywał osobiście papież, a w razie jego nieobecności - kardynał, przewodniczący wieczornej modlitwie. Z czasem wprowadzono zasadę, według której tylko Ojciec Święty, jeśli nawet nie przewodniczył nieszporom, osobiście poświęcał paliusze ${ }^{59}$.

${ }_{56}$ Por. A. ToRnIELl, I metropoliti riceveranno il pallio nelle loro diocesi, non più a Roma, http:// vaticaninsider.lastampa.it/vaticano/dettaglio-articolo/articolo/francesco-pallio-38832/ (15.03.2015).

${ }^{57}$ Tamże.

${ }^{58}$ Cyt. za: tamże, s. 451-454.

59 Tamże. 
Modlitwa poświęcenia paliusza ukazywała głęboką symbolikę biblijną, zaczerpniętą z obrazu Chrystusa Dobrego Pasterza, aby ci, którzy otrzymają tę wyjątkową szatę, byli Jego wiernymi naśladowcami. Po wezwaniu Adiutorium nostrum in nomine Domini, Dominus vobiscum papież proklamował:

Deus, pastor aeterne animarum, qui eas Ovium nomine designatas, per Jesum Christum Filium tuum, Beato Petro Apostolo eiusque successoribus, boni Pastoris typo regendas commisisti, atque Ipsis sacrarum vestium symbolis pastoralis curae documenta significari voluisti; effunde per ministerium nostrum super haec Pallia de beatorum Apostolorum Principium altari sumpta copiosam benedictionis et sanctificationis tuae gratiam, ut quam mystice repraesentant pastoralis officii plenitudinem atque excellentiam, pleno quoque operantur effectu. Humilitatis nostrae preces benignus excipe, atque eorumdem Apostolorum meritis et suffragis concede, ut quicumque ea, te largiente, gestaverit, intelligat se Ovium tuarum Pastorem, atque in opere exibeat, quod signatur in nomine. Sit boni magnique illius imitator Pastoris, qui errantem ovem humeris suis impositam caeteris adunavit, pro quibus animam posuit. Sit eius exemplo in custodia gregis sibi commissi sollicitus, sit vigil, sit circumspectus; ne qua ovis in morsus incidat fraudesque luporum. Sit discipline zelo districtus, quod perierat requirens, quod alienum reducens, quod confractum alligans, quod pingue et forte custodiens. Videat humeris suis impositiam Crucem, quam Filius tuus propositio sibi gaudio sustinere non recusavit, sitque illi crucifixus mundus et ipse mundo. Tollat iniectum collo suo evangelicum iugum, sitque ei ita leve ac suave ut in via mandatorum tuorum caeteris exemplo et observatione praecurrat. Sit ei hoc symbolum unitatis et cum Apostolica Sede communionis perfectae tessera, sit caritatis vinculum, sit divinae haereditatis funiculus, sit aeternae securitatis pignus, ot in die adventus et revelationis Magni Dei, Pastorumque Principis, Jesu Christi, cum ovibus sibi creditis, stola potiatur immortalitatis et gloriae. Per eundem Dominum nostrum etc ${ }^{60}$.

Po zakończonej modlitwie papież kropił paliusze wodą święconą i okadzał je. Następnie wkładano je do srebrnej skrzyni i umieszczano obok relikwii św. Piotra $^{61}$. Następnego dnia zakrystianin papieski, który jako jedyny posiadał klucze do skrzyni i sprawował pieczę nad paliuszami, zabierał je i przekazywał do dalszej celebracji ${ }^{62}$.

${ }^{60}$ Cyt. za: tamże, s. 452.

${ }^{61}$ Por. M. Righetti, Manuale di storia liturgica, t. I, s. 631.

${ }^{62}$ Por. M. Nowodworski, Encyklopedia, s. 50. 
Od momentu pojawienia się pierwszych wzmianek na temat paliusza oczywistym było, że wręcza je sam papież. Nowowiejski podkreśla, że w XII w. powstał obowiązek wystosowania prośby o paliusz skierowanej przez metropolitów do Ojca Świętego w czasie nie dłuższym niż trzy miesiące od daty ich ustanowienia ${ }^{63}$. W przypadku niemożności stawienia się osobiście metropolity w Stolicy Świętej, mógł on ustanowić swojego delegata, aby odebrał paliusz z rąk papieża. Istniała również wyraźnie podkreślana hierarchia w obrzędzie nadawania paliusza: jeśli metropolita nie był kardynałem, paliusz nakładał w imieniu papieża pierwszy z kardynałów diakonów, kardynałom natomiast Ojciec Święty nakładał osobiście. Niezależnie od osoby szafarza, formuła obrzędu nałożenia paliusza pozostawała niezmienna:

\begin{abstract}
Ad honorem Omnipotentis Dei et Beatae Mariae semper Virginis, atque beatorum Apostolorum Petri et Pauli, nec non Ecclesiae tibi commissae, tradiamus tibi Pallium de corpore Sancti Petri sumptum, in quo est plenitudo pontificalis officii, cum patriarchalis (vel archiepiscopalis) nominis appellatione: ut utaris eo intra Ecclesiam tuam certis diebus, qui exprimuntur in privilegiis ab Apostolica Sede concessis. In nomine Patris et Filii et Spiritus Sancti. Amen ${ }^{64}$.
\end{abstract}

Delegat metropolity wracał z paliuszem do diecezji i podczas uroczystej Eucharystii odbywał się obrzęd nałożenia paliusza nowo mianowanemu arcybiskupowi. Po komunii św. arcybiskup bądź jeden z biskupów upoważnionych przez Stolicę Apostolską przewodniczył uroczystemu obrzędowi. Paliusz, przykryty jedwabnym welonem, kładziono na ołtarzu; następnie, po błogosławieństwie, główny celebrans ubrany w kapę oraz mitrę siadał przed ołtarzem, by wysłuchać prośby nowego metropolity skierowanej do Stolicy Apostolskiej ${ }^{65}$. Następnie główny celebrans wstawał i nakładał paliusz na ramiona elekta, wypowiadając cytowaną wyżej formułę: Ad honorem Omnipotentis Dei... ${ }^{66}$

${ }^{63}$ Por. A. NowowIEJSKI, Wykład Liturgji, s. 452.

${ }^{64}$ Cyt. za: tamże, s. 453: „Na cześć Wszechmocnego Boga i błogosławionej Maryi zawsze Dziewicy i błogosławionych Apostołów Piotra i Pawła, tudzież papieża naszego N. i świętego Rzymskiego Kościoła, równie jak Kościoła Tobie powierzonego, dajemy Ci paliusz zdjęty z ciała błogosławionego Piotra, w którym jest pełność biskupiego urzędu, z tytułem arcybiskupim, abyś używał go w kościele swoim w dniach oznaczonych przez Stolicę Apostolską. W imię Ojca i Syna, i Ducha Swiętego. Amen".

${ }^{65}$ Cyt. za: A. Nowowiejski, Wyktad Liturgji, s. 453: Ego N. electus Ecclesiae N., instanter, instantius et instantissime peto mihi dari et assignari pallium de corpore beati Petri sumptum: in quo est plenitudo pontificalis offici.

${ }^{66}$ Zob. tamże, s. 453. 
Po nałożeniu paliusz ozdabiano szpilkami: pierwszą szpilkę diakon przymocowywał do krzyża znajdującego się na paliuszu z przodu ornatu, następnie do krzyża na lewym ramieniu, trzecią zaś do krzyża na plecach ${ }^{67}$. Obrzędy te obecne były w Kościele jeszcze w Pontificale Romanum ${ }^{68}$ z 1962 r.

Pontyfikał przewidywał obrzęd nałożenia paliusza nowym metropolitom tuż po homilii, podczas Mszy św. sprawowanej przez papieża w Bazylice watykańskiej 29 czerwca. Najpierw kardynał protodiakon przedstawiał Ojcu Świętemu metropolitów, zwracając się do niego w następujących słowach:

Beatissime Pater, Reverendissimi Patres Archiepiscopi hic stantes, Sanctitati Vestras et Apostolicae Sedi fide et devotione addictissimi, humiliter postulat ut Pallium de Confessione beati Petri sumptum, significans quidem potestatem qua, in communione cum Ecclesia Romana, Metropolita in propria provincia iure instruitur, a Sanctitate Vestra sibimetipsis tradatur ${ }^{69}$.

Po przedstawieniu metropolitów, przyjmujący paliusz w postawie stojącej przed Ojcem Świętym odczytywał następującą formułę:

Ego N, Archiepiscopus N., beato Petro Apostolo, Sanctae, Apostolicae, Romanae Ecclesiae, ac tibi, Summo Pontifici, tuisque legitimus Successoribus semper Fidelis ero et oboediens. Ita me Deus omnipotens adiuvet ${ }^{70}$.

Następnie papież dokonywał poświęcenia paliuszy, wypowiadając modlitwę w postawie stojącej z pastorałem oraz z nałożoną mitrą:

Deus, Pastor aeterne animarum, qui eas ovium nomine designatas per Iesum Christum Filium tuum, Beato Petro Apostolo, eiusque Successoribus, boni pastoris typo regendas commsisti, per ministerium nostrum, effunde benedictionis tuae gratami super haec Pallia quibus symbolis pastoralis curie documenta significare voluisti. Humilitatis nostrae preces beningus excipe, atque Apostolorum meritis et suffragiis concede, ut quicumque ea, te largiente gestaverit, intellegat se ovium tuarum Pastorem, atque in opere exibeat, quod signatur in nomine. Tollat iniectum collo suo evangelicum iugum, sitque ei ita leve ac suave, ut in mandatorum quorum exemplo

\footnotetext{
${ }^{67}$ A. NowowiejSKI, Wyktad Liturgji, s. 453.

${ }^{68}$ Pontificale Romanum (editio typica), Vaticanum 1962, s. 89.

69 Tamże.

${ }^{70}$ Tamże.
} 
et observatione praecurrens, in loco pascuae tuae perpetuo collocari mereatur. Per Christum Dominum nostrum. Amen ${ }^{71}$.

Ojciec Święty kończył modlitwę, siadając bez mitry i pastorału:

\begin{abstract}
Ad omnipotentis Dei gloriam atque ad laudem beatae Mariae semper Virginis et beatorum Apostolorum Petri et Pauli, ad decorem Sedium Vobis commissarum, in signum potestatis metropolitanae, tradimus Vobis Pallium de Confessione beati Petri sumptum, ut eo utamini intra fines provinciae ecclesiasticae vestrae. Sit Vobis hoc Pallium symbolum unitatis et cum Apostolica Sede communionis tessera; sit vinculum caritatis et fortitudnis incitamentum, ut die adventus et revelationis magni Dei pastorumque principia Iesu Christi, cum ovibus Vobis creditis scola potiamini immortalitatis et gloriae. In nomine Patris, et Filii, et Spiritus Sancti. Amen ${ }^{72}$.
\end{abstract}

Następnie papież nakładał paliusze na ramiona metropolitów i pozdrawiał ich indywidualnie: Pax tibi. Metropolita odpowiadał: Et cum spiritu tuo. W tym czasie schola wykonywała werset: Euntes in mundor universum, praedicate Evangelium omni creaturae.

W wyjątkowych okolicznościach paliusz mógł być nałożony przez delegowanego przez Stolicę Apostolską biskupa w diecezji elekta. Wzmiankę o tym znajdujemy w Pontificale Romanum z 1962 r. Po komunii św. biskup celebrujący Eucharystię siadał w wyznaczonym dla niego miejscu przed ołtarzem, na którym znajdował się owinięty w jedwab paliusz. Następnie główny celebrans przyjmował od elekta przysięgę wierności:

Ego N. Electus Ecclesiae N. ab hac hora in antea fidelis et obediens ero Beato Petro Apostolo, sanctaeque Romanae Ecclesiae et Domino nostro, Domino N. Papae N., suisque Successoribus canonice intrantibus Non ero in consilio aut consensu vel facto... ${ }^{73}$

Następnie biskup-delegat, trzymając w rękach Ewangeliarz, na którym elekt kładł dłoń, przyjmował przysięgę zakończoną słowami: Sic me Deus adiuvet, et haec sancta Dei Evangelia. Celebrans odpowiadał: Deo gratias, po czym biorąc z ołtarza paliusz, nakładał na ramiona elekta, wypowiadając słowa formuły: $A d$

\footnotetext{
${ }^{71}$ Tamże.

72 Tamże.

73 Tamże.
} 
honorem omnipotentis Dei... ${ }^{74}$ Następnie biskup metropolita, z paliuszem na ramionach, błogosławił zgromadzony lud.

Podczas konsystorza 18 lutego 2012 r. obrzędy związane z kreacją nowych kardynałów poprzedziły sprawowanie Eucharystii; podobnie też pobłogosławienie i nałożenie paliuszy nowo mianowanym metropolitom 29 czerwca 2012 r. odbyło się przed Mszą św. ${ }^{75}$ Sam ryt błogosławieństwa i nałożenia paliusza pozostał niezmienny, jedynie zamiast po homilii poprzedza on Eucharystię. Papież Benedykt XVI zaaprobował tę zmianę 15 maja 2012 r. ${ }^{76}$ Argumentowana była ona brakiem sakramentalnego charakteru obrzędu oraz przyczyniała się do skrócenia celebracji, zwłaszcza by sprawowania Eucharystii nie przerywać długim obrzędem, który mógł utrudniać uważne i pobożne w niej uczestnictwo ${ }^{77}$.

W Ceremoniale Episcoporum ${ }^{78}$ znajdujemy obrzęd nałożenia paliusza poza Rzymem, który powinien odbyć się podczas święceń biskupich - przed nałożeniem mitry i tuż po przekazaniu pierścienia. Jeżeli natomiast nie można połączyć go z obrzędem udzielenia święceń, można dokonać nałożenia paliusza podczas ingresu metropolity do swojego kościoła katedralnego. W obydwu sytuacjach nałożenia paliusza dokonuje biskup delegowany przez Stolicę Apostolską. Obrzęd ma miejsce na początku Mszy św.: diakon przynosi paliusz i kładzie go na ołtarzu. Upoważniony przez Ojca Świętego biskup wyjaśnia znaczenie nadania paliusza. W sytuacji przyjęcia paliusza powiązanej z objęciem katedry (si traditio palli coniungitur cum receptione Episcopi in eius ecclesiam cathedralem), diakon odczytuje nominację Stolicy Apostolskiej (mandatum apostolicum). Po pozdrowieniu wiernych lub - w przypadku ingresu - po odczytaniu nominacji elekt klęka przed delegowanym biskupem, składa przysięgę oraz wyznanie wiary. Następnie biskup odbiera od diakona paliusz i nakłada go na ramiona nowego metropolity, wypowiadając nieco zmodyfikowane, cytowane wcześniej słowa: Ad omnipotentis Dei gloriam atque ad laudem beatae Mariae semper Virginis et beatorum Apostolorum Petri et Pauli, nomine Romani Pontificis, Papae N., ... ${ }^{79}$ Po tym obrzędzie opuszcza się akt pokuty i Eucharystię sprawuje się według stałego porządku.

74 Pontificale Romanum, s. 89..

75 Zob. Urzad ds. Papieskich Celebraci Liturgicznych, Nowy obrzęd błogostawienia i nałożenia paliusza, „Notitiae” 49 (2012), s. 289-293.

${ }^{76}$ Tamże.

77 Tamże.

${ }^{78}$ Caeremoniale Episcoporum ex decreto Sacrosancti Oecumenici Concilii Vaticani II instauratum auctoritate Ioannis Pauli PP. II promulgatum, Città del Vaticano 20083 , s. 270-271.

79 Tamże, s. 271; tłumaczenie: „Na chwałę Boga wszechmogącego, na cześć Najświętszej Maryi Panny oraz świętych Apostołów Piotra i Pawła, w imieniu Biskupa Rzymskiego, papieża N. i święte- 
Ojciec Święty Franciszek zrezygnował ze zwyczaju nakładania paliusza na ramiona metropolitów. 12 stycznia 2015 r. został wystosowany list przez mistrza papieskich ceremonii liturgicznych Guido Mariniego do nuncjuszy apostolskich na całym świecie, którego treść została przekazana przez watykanistę Geralda O'Connella ${ }^{80}$. Ceremoniarz papieski zakomunikował postanowienie Ojca Świętego, zgodnie z którym publiczna uroczystość wręczenia paliuszy nowym arcybiskupom metropolitom odbywać się będzie od tej pory w ich diecezjach, a nie, jak dotąd, w Watykanie. Postanowił, że paliusze będą błogosławione podczas Mszy św. w uroczystość świętych Piotra i Pawła, ale nakładane przez nuncjuszy apostolskich - dla podkreślenia ścisłej łączności ze Stolicą Apostolską - w diecezjach nowych arcybiskupów metropolitów. Zmiana ta została wprowadzona dla podkreślenia synodalności, gdyż na uroczystość nałożenia paliusza mają być zapraszani do miejscowej katedry wszyscy biskupi posługujący w metropolii. Kolejnym argumentem jest chęć pokazania i podkreślenia mocnych relacji, jakie łączą metropolitę z jego Kościołem lokalnym, oraz umożliwienie większej liczbie wiernych uczestniczenia w tej podniosłej uroczystości ${ }^{81}$.

Po modyfikacjach dokonanych w 2015 r. obrzęd przekazania i nałożenia podzielony został zatem na dwie części.

\subsection{Celebracja w Watykanie ${ }^{82}$}

Po pozdrowieniu na początku Mszy św. diakoni przynoszą paliusze zabrane z konfesji św. Piotra, po czym następują kolejno:

Metropolitarum Prcesentatio:

Kardynał protodiakon prezentuje Ojcu Świętemu metropolitów:

go Kościoła Rzymskiego, ku ozdobie powierzonej ci biskupiej stolicy N., na znak władzy metropolitalnej, nakładamy tobie paliusz wzięty z konfesji świętego Piotra. Noś go w granicach swojej prowincji kościelnej jako symbol jedności i więzi miłości, oznakę komunii ze Stolicą Apostolską i zachętę do męstwa. Obyś w dniu przyjścia i objawienia się wielkiego Boga i Najwyższego Pasterza Jezusa Chrystusa, razem z powierzoną ci owczarnią został przyobleczony szatą nieśmiertelności i chwały. W imię Ojca i Syna, i Ducha Świętego. Amen" (Ceremoniat liturgicznej postugi biskupów odnowiony zgodnie z postanowieniem Świętego Soboru Watykańskiego II wydany z upoważnienia Jana Pawła II dostosowany do zwyczajów diecezji polskich, Katowice 2013, s. 247-248).

${ }^{80}$ Por. A. ToRnIELl, I metropoliti riceveranno il pallio nelle loro diocesi, non più a Roma, http://vaticaninsider.lastampa.it/vaticano/dettaglio-articolo/articolo/francesco-pallio-38832/ (30.01.2015), s. 1.

${ }^{81}$ Tamże.

82 Ufficio delle Celebrazioni Liturgiche del Sommo Pontefice, Libretto liturgico, Santi Pietro e Paolo Apostoli. Solennità - Benedizione dei palli e celebrazione Eucaristica presiedute dal Santo Padre Francesco, 29 giugno 2017, Città del Vaticano 2017, s. 9-11. 
Beatissime Pater, Reverendissimi Patres Archiepiscopi Sanctitati Vestrce et Apostolica Sedi fide et devotione addictissimi, humiliter postulant ut Pallium de Confessione beati Petri sumptum, significans quidem potestatem qua, in communione cum Ecclesia Romana, Metropolita in propria provincia iure instruitur, a Sanctitate Vestra sibimetipsis tradatur.

Pallia, quibus Sanctitas Vestra hodie benedixit, cunctis Archiepiscopis Metropolitis, vertente anno electis, unicuique in propria Ecclesia Metropolitana, a Pontificio Legato imponentur. Archiepiscopi hic adstantes nunc coram Sanctitate Vestra hanc iuramenti formulam pronuntiabunt.

\section{Po przedstawieniu metropolici wypowiadają formułę:}

Iurisiurandi Formula:

Ego N., Archiepiscopus N., beato Petro apostolo, Sanctce, Apostolica, Romance Ecclesice, ac tibi, Summo Pontifici, tuisque legitimis Successoribus semper fidelis ero et oboediens. Ita me Deus omnipotens adiuvet.

\section{Następnie Ojciec Święty proklamuje modlitwę błogosławieństwa paliuszy:}

\section{Palliorum Benedictio:}

Deus, Pastor aeterne animarum, qui eas ovium nomine designatas per Iesum Christum Filium tuum, beato Petro Apostolo, eiusque Successoribus, boni Pastoris typo regendas commisisti, per ministerium nostrum effunde benedictionis $\uparrow$ tuae gratiam super haec Pallia quibus symbolis pastoralis curae documenta significare voluisti. Humilitatis nostrae preces benignus excipe, atque Apostolorum meritis et suffragiis concede, ut quicumque ea, te largiente, gestaverit, intellegat se ovium tuarum Pastorem, atque in opere exhibeat, quod signatur in nomine. Tollat iniectum collo suo evangelicum ingum, sitque ei ita leve ac suave, ut in via mandatorum tuorum exemplo et observatione praecurrens, in loco pascuae tuae perpetuo collocari mereatur. Per Christum Dominum nostrum. R. Amen.

Po modlitwie następuje Kyrie eleison..., natomiast przekazanie paliusza dokonuje papież poza liturgią in modo privato. 


\subsection{Celebracja w diecezji (stolicy metropolitalnej) ${ }^{83}$}

Obrzęd rozpoczyna się na początku Mszy św. Po pozdrowieniu nuncjusz apostolski (celebrans) wyjaśnia sens nałożenia paliusza, następnie arcybiskup metropolita klęka przed celebransem, który nakłada mu paliusz, wypowiadając następujące słowa:

Na chwałę wszechmogącego Boga, błogosławionej Maryi zawsze Dziewicy i błogosławionych Apostołów Piotra i Pawła, w imieniu Papieża N., i Świętego Kościoła Rzymskiego, w uznaniu godności powierzonej tobie biskupiej stolicy N., nakładam ci paliusz wzięty, ołtarza przy konfesji świętego Piotra, jako znak władzy metropolity. Paliusz ten, który możesz nosić w granicach twojej prowincji kościelnej, niech będzie dla ciebie symbolem jedności i znakiem komunii ze Stolicą Apostolską; niech będzie więzią miłości i wezwaniem do ewangelicznego męstwa, abyś w dniu przyjścia i objawienia się wielkiego Boga i Księcia Pasterzy, Jezusa Chrystusa, wraz z owczarnią tobie powierzoną, został przyobleczony szatą nieśmiertelności i chwały. W imię Ojca i Syna i Ducha Świętego. Amen.

Następuje „Chwała na wysokości Bogu...”

Należy dodać, że posiadanie paliusza przez metropolitów wymagane jest Kodeksem Prawa Kanonicznego, gdzie w kan. 437 czytamy:

$\S 1$. W ciągu trzech miesięcy od przyjęcia konsekracji biskupiej, a gdy jest już konsekrowany, od powierzenia kanonicznego, metropolita obowiązany jest, osobiście lub przez pełnomocnika, prosić Biskupa Rzymskiego o paliusz, który stanowi znak władzy, jaką - pozostając we wspólnocie z Kościołem Rzymskim - jest wyposażony na mocy prawa we własnej prowincji.

$\S 2$. Zachowując przepisy liturgiczne, metropolita może używać paliusza w każdym kościele swojej prowincji kościelnej, której przewodniczy, nigdy jednak poza nią, nawet za zgodą biskupa diecezjalnego.

$\S 3$. Jeśli metropolita zostaje przeniesiony na inną stolicę metropolitalną, potrzebuje nowego paliusza.

83 Zob. T. KoŁodzieıczyk (red.), Msza święta z nałożeniem paliusza Księdzu Arcybiskupowi Markowi Jędraszewskiemu, 22 października A.D. 2017, Kraków 2017, s. 11-12. 
Należy dodać, że papież może nosić paliusz na całym świecie, gdyż jest to znak jego najwyższej jurysdykcji.

\section{Teologia i symbolika paliusza}

Formuła wypowiadana podczas nałożenia paliusza wskazuje na jego teologię i jednocześnie symbolikę. Jest on zatem symbolem jedności, znakiem komunii ze Stolicą Apostolską i więzi miłości oraz wezwaniem do ewangelicznego męstwa.

Amalarius z Metz, liturgista żyjący na przełomie VIII i IX w., tłumaczy z kolei, że paliusz jest ,rodzajem naszyjnika, który zwykle otrzymywali ci, którzy przepisowo walczą. Tym darem zachęca się innych do przepisowej walki" ${ }^{84}$. To zwycięstwo należy się walczącym dla Jezusa Chrystusa.

Z kolei papież Innocenty III (1198-1216 r.) z kolei wyjaśniając teologiczne znaczenie paliusza, podkreśla, iż ci, którzy go noszą, winni odznaczać się roztropnością „Dobrego Pasterza” oraz sprawiedliwością w sądzeniu ${ }^{85}$.

Benedykt XVI w homilii inaugurującej pontyfikat ${ }^{86}$ (24 kwietnia 2005 r.) podał jeszcze inną symbolikę paliusza: to obraz Chrystusowego jarzma, czyli woli Bożej, którą przyjmujemy ${ }^{87}$. Nie jest on wewnętrznym ciężarem, który przygniata i odbiera wolność, ale jest również wewnętrzną radością. Paliusz, wykonany z owczej wełny, symbolizuje także misję pasterską. Ukazuje zagubioną owieczkę, również tę chorą, zagubioną i słabą, którą pasterz bierze na swe ramiona i prowadzi do wód życia ${ }^{88}$. Po wtóre, nałożenie paliusza każdemu metropolicie uświadamia pasterskie obowiązki wobec powierzonych mu owiec. Dwa boki paliusza tkanego z wełny otaczają szyję i opadają z obu stron lewego ramienia, symbolizując owcę niesioną przez Dobrego Pasterza, który winien swe owce nosić na ramionach.

${ }^{84}$ Amalariusz z Metzu, Święte Obrzędy Kościoła, (Dzieła I), tłum. zbiorowe, Lublin 2016, s. 227. Twierdzenie to Amalariusz opierał na starożytnym zwyczaju, według którego żołnierze za męstwo w walce otrzymywali odznaczenie w postaci naszyjnika zawieszonego na piersiach.

${ }^{85}$ InNOCENZo III, Il Sacrosancto mistero, s. 97.

${ }^{86}$ Homilia podczas Mszy św. z okazji inauguracji pontyfikatu: In celebratione Initii Ministerii Petrini (24 kwietnia 2005), AAS 97 (2005), s. 710.

87 Tamże.

88 Tamże. 


\title{
Streszczenie
}

Nazwa „paliusz” pochodzi od łacińskiego słowa pallium, które oznacza płaszcz. To pas z białej wełny noszony na ramionach, będący elementem stroju liturgicznego metropolitów. Zakładany jest na ornat i opuszczany końcami na piersi i plecy. Ozdobiony jest wyszytymi sześcioma czarnymi równoramiennymi krzyżami, trzema szpilkami, zakończony również czarnymi, jedwabnymi fragmentami. Noszony jest wyłącznie jako element stroju liturgicznego, mający podkreślić funkcję i władzę metropolity w zgromadzeniu oraz jego łączność ze Stolicą Apostolską. Liturgiczny obrzęd nałożenia paliusza przeżywał w historii - od wczesnego średniowiecza do czasów współczesnych, różne modyfikacje, by w 2015 r. przyjąć obecny kształt. Obrzęd poświęcenia i nałożenia paliusza każdemu metropolicie uświadamia pasterskie obowiązki wobec powierzonych mu owiec. Jest widocznym symbolem jedności, znakiem komunii i więzi miłości ze Stolicą Apostolską oraz wezwaniem do ewangelicznego męstwa.

Słowa kluczowe: paliusz, obrzęd nałożenia paliusza, modlitwa poświęcenia paliusza, teologia paliusza, liturgia.

The Rite for Imposing the Pallium on Metropolitan Archbishops - History and Theology

\begin{abstract}
The term pallium derives from Latin and signifies "coat". It is a strip made of white wool, worn on shoulders, used as an element of a liturgical attire of a Metropolitan Archbishop. The pallium is decorated with six Greek crosses, three pins and silk black trimmings. Its meaning is to emphasize the liturgical function and power of a Metropolitan Archbishop and his unity with the Holy See. The liturgical rite for imposing the pallium in the history had many modifications, and the present form was approved by Pope Francis in 2015. The rite itself underlines the pastoral responsibility of the Shepard towards his flock. It is a visible sign of unity, of the communion with Holy See and it is also a call for evangelical fortitude.
\end{abstract}

Keywords: Pallium, Rite for Imposing the Pallium, Prayer for Benediction of Pallium, Theology of Pallium, Liturgy. 


\section{Bibliografia}

Amalariusz z Metzu, Święte Obrzędy Kościoła, (Dzieła I), tłum. zbiorowe, Lublin 2016.

Braun J., Die liturgischen Paramente in Gegenwart und Vergangenheit. Ein Handbuch der Paramentik, Bonn 2005.

Caeremoniale Episcoporum ex decreto Sacrosancti Oecumenici Concilii Vaticani II instauratum auctoritate Ioannis Pauli PP. II promulgatum, Città del Vaticano $2008^{3}$.

Ceremoniat liturgicznej postugi biskupów odnowiony zgodnie z postanowieniem Świętego Soboru Watykańskiego II wydany z upoważnienia Jana Pawła II dostosowany do zwyczajów diecezji polskich, Katowice 2013.

Baron A., Pietras H. (red.), Dokumenty Soborów Powszechnych. Tekst grecki, taciński, polski, t. II, Kraków 2003.

Gregorius Magnus, Epistolae II, 17-18, [Corpus Christianorum Series Latina 140], Turnhout 2015, s. 102-105.

Homilia podczas Mszy św. z okazji inauguracji pontyfikatu: „, In celebratione Initii Ministerii Petrini" (24 kwietnia 2005 r.), AAS 97 (2005), s. 707-748.

Innocenzo III, Il Sacrosancto mistero dell'altare, S. Fioramonti, M. Sodi (wyd.), Città del Vaticano 2002.

Isidorus di Pelusio, Epistula I, 136, w: J.P. Migne, Patrologiae Cursus Completus. Series Greca 78 (PG), Paris 1854, s. 271.

Jougan A., Stownik kościelny łacińsko-polski, Sandomierz $2013^{5}$.

Kodeks Prawa Kanonicznego, Poznań 1984.

Andrieu M. (wyd.), Le Pontifical de Guillaume Durand (Studi e Testi 88), Città del Vaticano 1940.

Lewandowicz J., Paliusz w korespondencji Świętego Grzegorza Wielkiego, „Vox Patrum" 24 (2004), t. XLVI-XLVII, s. 363-370.

Vogel C., L. Duchesne (wyd.), Liber pontificalis. Texte introduction, et commentaire, t. I, Paris 1955-1957.

Marini P., Ceremoniarz papieski. Rozmowy o liturgii przeprowadzit D. Chivot i V. Cabanac, thum. M. Romanek, Katowice 2010.

Marini P., Liturgia i Piękno, tłum. W. Dzieża, Pelplin 2007.

Martí Bonet J.M., El palio. Insignia pastoral de los papas y arzobispos, Madrid 2008.

Mathews T.F., Scontro di dei. Una reinterpretazione dell'arte paleocristiana, Milano 2005. 
Morin G., Le pallium, „Le Messager des fidèles. Revue Bénédictine” 6 (1889), s. 258-266.

KoŁodziejczyк T. (red.), Msza Święta z nałożeniem paliusza Księdzu Arcybiskupowi Markowi Jędraszewskiemu, 22 października A.D. 2017, Kraków 2017.

Nadolski B., Paliusz w: tenże, Leksykon Liturgii, Poznań 2006, s. 1139-1140.

Nadolski B., Leksykon liturgii, Poznań 2006.

Nowodworski M., Encyklopedia Kościelna, Warszawa 1892.

Nowowiesski A., Wykład Liturgji Kościoła Katolickiego, t. II, cz. 1: O środkach rozwinięcia kultu, Warszawa 1902.

Pontificale Romanum (editio typica), Vaticanum 1962.

Righetti M., Manuale di storia liturgica, t. I: Introduzione generale, Milano $2005^{2}$.

Schatz K., Prymat papieski od początków do współczesności, tłum. E. Marszał, J. Zakrzewski, Kraków 2004.

Superson J., Paliusz - wspótczesna forma i teorie o pochodzeniu, „Ruch Biblijny i Liturgiczny", t. LXV (2012), nr 1, s. 85-100.

SzcZĘSNY P., Paliusz. Historia - liturgia - teologia (praca magisterska w bibliotece UMK), Toruń 2015.

Tornielli A., I metropoliti riceveranno il pallio nelle loro diocesi, non più a Roma, http:/vaticaninsider.lastampa.it/vaticano/dettaglio-articolo/articolo/francesco-pallio-38832/, (30.01.2015).

Ufficio delle Celebrazioni Liturgiche del Sommo Pontefice, Libretto liturgico, Santi Pietro e Paolo Apostoli. Solennità - Benedizione dei palli e celebrazione Eucaristica presiedute dal Santo Padre Francesco, 29 giugno 2017, Città del Vaticano 2017.

Urząd ds. Papieskich Celebracji Liturgicznych, Nowy obrzęd błogostawienia i nałożenia paliusza, „Notitiae” 49 (2012), s. 289-293.

Valenziano M.G., Il pallium papale, w: Ufficio delle Celebrazioni Liturgiche del Sommo Pontefice, Inizio del ministero Petrino del vescovo di Roma Benedetto XVI, Città del Vaticano 2006, 360-377.

Vita S. Cesarii, 4, 20, w: J.P. Migne, Patrologiae Cursus Completus. Series Latina 67, Paris 1844-1864, s. 1016.

Vita S. Fulgentii, w: J.P. Migne, Patrologiae Cursus Completus. Series Latina 18, 37, 65, Paris 1844-1864, s. 136. 
KAROL LitAWA, doktor liturgii (PIL, Rzym), prezbiter archidiecezji łódzkiej, wykładowca liturgiki w Wyższym Seminarium Duchownym, Instytucie Teologicznym w Lodzi oraz na Uniwersytecie Papieskim Jana Pawła II w Krakowie, przewodniczący Komisji ds. Liturgii w Archidiecezji Łódzkiej. E-mail: litawa.k@archidiecezja.lodz.pl. 